Thorax (1968), 23, 216.

\title{
Lung abscess in childhood
}

\author{
PATRICIA H. MARK AND J. A. PETER TURNER ${ }^{1}$ \\ From the Department of Paediatrics, Faculty of Medicine, University of Toronto, and the Hospital for Sick \\ Children, Toronto, Canada
}

Lung abscess continues to be a significant problem in childhood. Eighty-three cases of this condition have been reviewed. From the available data these have been found to fall into two groups which have been classified as primary and secondary. Consideration of the aetiology has revealed that the commonly quoted predisposing features, namely tonsillectomy and foreign body aspiration, are no longer of such paramount importance. The causative organism is a staphylococcus in the majority of cases. This is at variance with other published findings. The more general use of antibiotics in all respiratory diseases is responsible for some of the changing patterns noted. The management of lung abscess in childhood also presents a changing picture. Bronchoscopy is being supplanted by more conservative measures.

A study of relevant publications during the last 10 years reveals a paucity of literature on the subject of lung abscess in childhood. The object of this survey is to review all the documented cases of pulmonary abscess admitted to the Hospital for Sick Children, Toronto, during the years 1956 to 1965 inclusive with the intention of examining the status of lung abscess from the standpoint of aetiological factors and in the light of current trends in therapy.

\section{MATERIAL AND METHODS}

During the years 1956 to 1965,83 cases of lung abscess were admitted to the Hospital for Sick Children. Cases of cystic fibrosis of the lung, bronchiectasis, and infected congenital lung cysts have been excluded from the series.

For case selection we have defined lung abscess as a circumscribed area of suppuration in the lung parenchyma which subsequently breaks down, with resulting necrosis. This is either diagnosed pathologically or inferred radiologically.

A study of the cases with such a pathological process revealed that the 83 cases were divisible into two groups. The first, designated primary, comprised those cases that occurred in children who had been previously well or in whom a recent illness was not considered to be related to the subsequent formation of lung abscess.

One possible exception, a case of furunculosis, is described.

In the remaining cases abscesses were found to be coexistent with other serious diseases and known

${ }_{1}$ Requests for reprints to Dr. J. A. P. Turner, the Hospital for Sick Children, Toronto, Canada septicaemia. These have been classified as secondary lung abscesses.

According to the above definition, 25 of our total group were primary and 58 were secondary.

PRIMARY LUNG ABSCESS

Age There were no cases of primary lung abscess in infants under 1 month old (Table I).

T A B L E I

PRIMARY LUNG ABSCESS: AGE DISTRIBUTION

\begin{tabular}{|c|c|c|}
\hline Age & & No. \\
\hline $\begin{array}{ll}0-1 \text { month } & \ldots \\
1 \text { month-1 year } \\
1-5 \text { years } & \ldots \\
5-10 \text { years } & \ldots \\
10-14 \text { years } & \ldots\end{array}$ & $\begin{array}{l}\cdots \\
\cdots \\
\cdots \\
\cdots\end{array}$ & $\begin{array}{r}0 \\
6 \\
10 \\
6 \\
3\end{array}$ \\
\hline Total & $\ldots$ & 25 \\
\hline
\end{tabular}

Sex Nineteen of the affected children were boys. A preponderance of males in studies of patients with lung abscess has previously been described by Schweppe, Knowles, and Kane (1961), Pickar and Ruoff (1959), and Bernhard, Malcolm, and Wylie (1963).

Aetiology Of the 25 cases, 14 children had no history of any pre-existing illness. Four had had some indefinite respiratory disease in the previous nine $\square$ months; three gave a history of recent measles, and all had made an uneventful recovery. There was one controlled diabetic in the series. One child had undergone tonsillectomy six weeks previously, but no post- $Q$ operative problems were reported. One child had had $\sigma$ a pneumonia with associated gastro-enteritis and 
otitis media two weeks before the onset of the symptoms that brought him to hospital. The same child had a history of choking on a peanut shell one month before the onset of symptoms. Subsequently, no trace of foreign body was found at bronchoscopy. One child had had furuncles on the buttocks four weeks before the onset of symptoms of lung abscess. Although these furuncles had cleared up quickly and completely, a connexion between them and subsequent lung abscess formation cannot be discounted.

Duration of Respiratory Symptoms Eight children had respiratory symptoms for less than one week, 11 had symptoms for between one and two weeks, three from two to four weeks, and three from four to 12 weeks.

Clinical Features All children had fever, anorexia, and general malaise. The remaining features are shown in Table II. It is interesting to note that 16

\section{T A B L E I I}

\section{PRIMARY LUNG ABSCESS: CLINICAL FEATURES}

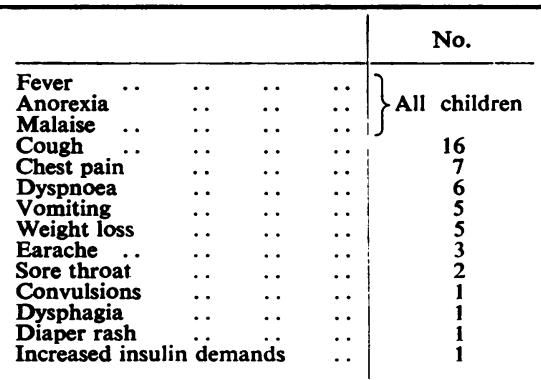

of the 25 children had a significant cough. No other one feature was so consistently found. Chest pain was a complaint of most of the older children in the series. Similar clinical features were found by Moore and Battersby (1960). Clubbing of the fingers, however, was not found in any of our cases.

Bacteriology Pyogenic staphylococcus was cultured from the pharyngeal secretions of 14 children, either by itself or in association with other organisms. Haemophilus influenzae type B was next in frequency being recovered from six cases. The significance of this particular organism is always in doubt, since it is commonly found with many respiratory illnesses in this institution (Table III).

Radiology In all cases the radiological appearance was that of a circumscribed radiodensity in the lung field. In 16 an air fluid level was seen during the course of the illness (see Figure). With regard to the site of the abscesses, nine were in the left lower lobe,
T A B L E I I I

PRIMARY LUNG ABSCESS: BACTERIOLOGY

\begin{tabular}{|c|c|c|c|}
\hline Organism & & & No. \\
\hline Pyogenic staphylococcus & .. & . & 11 \\
\hline H. influenzae, type В & .. & .. & 3 \\
\hline Pneumococcus $\quad \ldots$ & .. & .. & 2 \\
\hline Streptococcus viridans & . & .. & 1 \\
\hline Mixed organisms $\ldots \quad \ldots$ & . & . & 5 \\
\hline $\begin{array}{l}\text { Pyogenic staphylococcus } \\
\text { Enteric streptococcus }\end{array}$ & . & . & \\
\hline $\begin{array}{l}\text { Pyogenic staphylococcus } \\
\text { Haemolytic streptococcus }\end{array}$ & . & $\ldots$ & 1 \\
\hline $\begin{array}{l}\text { Pyogenic staphylococcus } \\
\text { Pneumococcus } \\
\text { H. influenzae }\end{array}$ & . & . & 1 \\
\hline $\begin{array}{l}\text { Pneumococcus } \\
\text { H. influenzae } \\
\text { Enteric streptococcus }\end{array}$ & & .. & 1 \\
\hline $\begin{array}{l}\text { H. influenzae } \\
\text { Streptocnicus viridans }\end{array}$ & & .. & 1 \\
\hline No organisms $\quad \ldots$ & .. & .. & 1 \\
\hline
\end{tabular}

seven in the right upper lobe, five in the right lower lobe, three in the left upper lobe, and one in the right middle lobe. This pattern of distribution is similar to that found by Bernhard et al. (1963) and Drake and Sones (1951). However, Moore and Battersby (1960) found that the right middle lobe was more commonly involved.

Treatment Appropriate antibiotic therapy was given in all cases. Bronchoscopy was performed in 18 patients, in 13 of whom an abscess cavity was found and aspirated. Two patients required thoracotomy and lobectomy.

Outcome All 25 patients made a satisfactory recovery with no sequelae.

SECONDARY LUNG ABSCESS There were 58 cases of secondary lung abscess in the series.

Age The distribution in the various age groups was markedly different from that of the primary group, the condition being found in younger children (Table IV).

Sex Of the 58 cases, 34 occurred in boys.

T A B L E IV

SECONDARY LUNG ABSCESS: AGE

\begin{tabular}{lll|c}
\multicolumn{2}{c|}{ Age } & No. \\
\hline 0-1 month & $\ldots$ & $\ldots$ & 18 \\
1 month-1 year & $\ldots$ & 18 \\
1-5 years & $\ldots$ & $\ldots$ & 14 \\
5-10 years & $\ldots$ & $\ldots$ & 7 \\
10-14 years & $\ldots$ & $\ldots$ & 1 \\
\hline \multicolumn{2}{c}{ Total } & $\ldots$ & 58
\end{tabular}




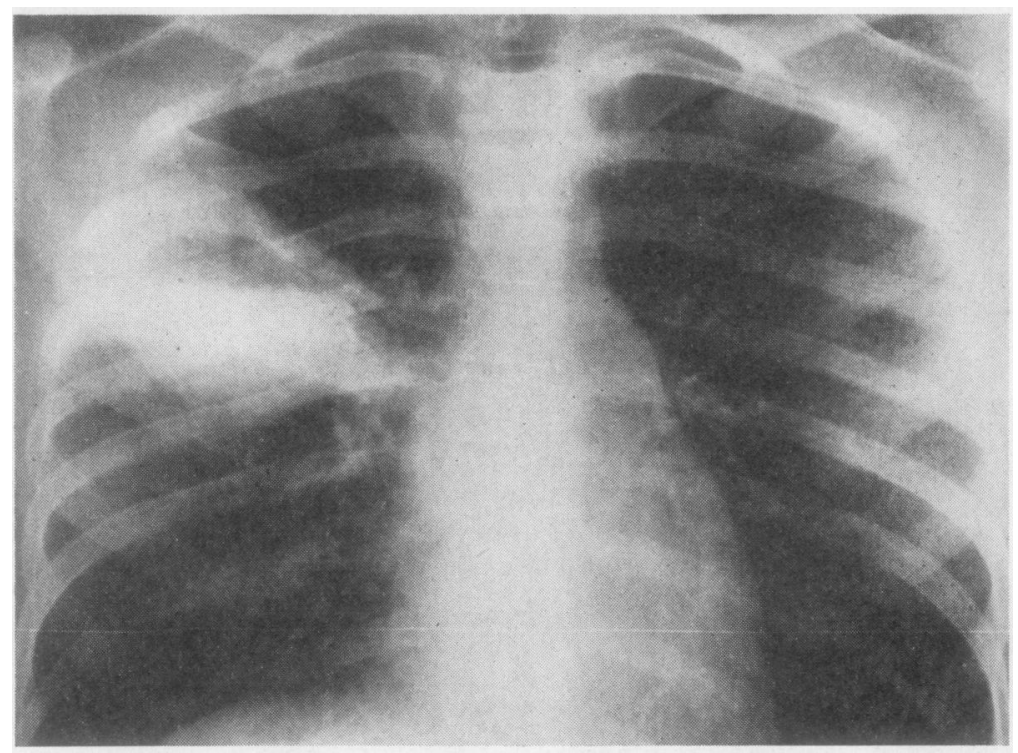

FIGURE (above and below). Primary lung abscess showing typical circumscribed lesion with an air fluid level.

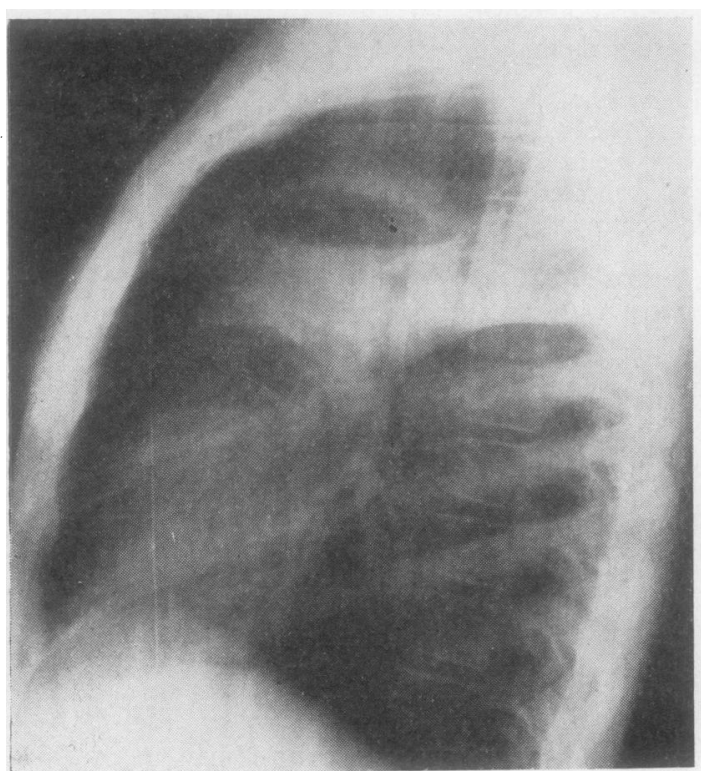

Aetiology Secondary lung abscess was found in association with many diseases. Staphylococcal pneumonia and pyopneumothorax were commonly found to precede the development of lung abscess. A significant number of cases occurred following major surgery (Table V).
T A B L E V

SECONDARY LUNG ABSCESS: PRE-EXISTING ILLNESS

\begin{tabular}{|c|c|c|c|c|}
\hline & & & & No. \\
\hline $\begin{array}{l}\text { None } \quad \cdots \\
\text { Respiratory disease }\end{array}$ & . & $\cdots$ & $\cdots$ & 一 \\
\hline \multicolumn{5}{|l|}{ Respiratory disease } \\
\hline \multirow{2}{*}{$\begin{array}{l}\text { Bronchopneumonia } \\
\text { and/or empyema }\end{array}$} & with & \multicolumn{2}{|c|}{ pneumothorax } & 10 \\
\hline & $\cdots \quad$. & . & . $\quad \cdots$ & 20 \\
\hline Measles .. . & . & . & . & 2 \\
\hline Gastro-enteritis .. & . & . & $\cdots$ & 4 \\
\hline Ear infections $\quad \ldots$ & . & $\cdots$ & $\cdots$ & $\begin{array}{r}3 \\
10\end{array}$ \\
\hline Post-operation . . & $\cdots$ & $\cdots$ & $\cdots$ & 10 \\
\hline Rectal abscess $\quad$. & . & . & $\cdots$ & 1 \\
\hline Meningitis $\quad$. & $\cdots$ & . & $\cdots$ & $\begin{array}{l}3 \\
4\end{array}$ \\
\hline Osteomyelitis $\quad \cdots$ & & & $\cdots$ & 4 \\
\hline \multicolumn{3}{|c|}{ Eczema with secondary infection } & . $\quad \cdots$ & 4 \\
\hline \multirow{2}{*}{\multicolumn{4}{|c|}{ Burns 1.}} & 4 \\
\hline & & & & $\begin{array}{l}4 \\
3\end{array}$ \\
\hline Congenital heart disease & & $\cdots$ & $\cdots \quad \cdots$ & $\mathbf{2}$ \\
\hline Asian flu $\quad \ldots$ & $\cdots$ & - & $\cdots$ & 2 \\
\hline Blood dyscrasias & $\cdots$ & . & $\cdots$ & 2 \\
\hline Hyperbilirubinaemia & $\cdots$ & $\cdots$ & $\cdots$ & 1 \\
\hline Hepatitis . & $\therefore$ & $\cdots$ & $\begin{array}{l}\cdots \\
\cdots\end{array}$ & 1 \\
\hline $\begin{array}{l}\text { Dysgammaglobulinaemi } \\
\text { Laryngeal condition }\end{array}$ & & $\cdots$ & 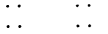 & 1 \\
\hline $\begin{array}{l}\text { Laryngeal condition } \\
\text { Nephrotic syndrome }\end{array}$ & $\begin{array}{l}\cdots \\
\cdots\end{array}$ & $\cdots$ & 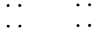 & 1 \\
\hline $\begin{array}{l}\text { Nephrotic syndrome } \\
\text { Typhoid fever } \quad . .\end{array}$ & $\cdots$ & $\because$ & $\cdots$ & $\overrightarrow{1}$ \\
\hline $\begin{array}{l}\text { Typhoid fever } \\
\text { Fanconi's anaemia }\end{array}$ & $\because$ & $\because$ & $\cdots$ & 1 \\
\hline Salicylate intoxication & $\cdots$ & $\cdots$ & $\ldots$ & 1 \\
\hline Riley-Day syndrome & . & . & $\cdots$ & 1 \\
\hline
\end{tabular}

Bacteriology The pyogenic staphylococcus was the most commonly isolated organism, being present in ${ }_{0}$ 38 cases. The remaining organisms were as shown $\stackrel{\square}{\circ}$ in Table VI. The Asian influenza virus was recovered $\overrightarrow{\mathbb{D}}$ from two children who were admitted during the $\frac{\text { 음 }}{\sigma}$ 1957 epidemic associated with this organism and who 
T A B L E V I

SECONDARY LUNG ABSCESS: BACTERIOLOGY

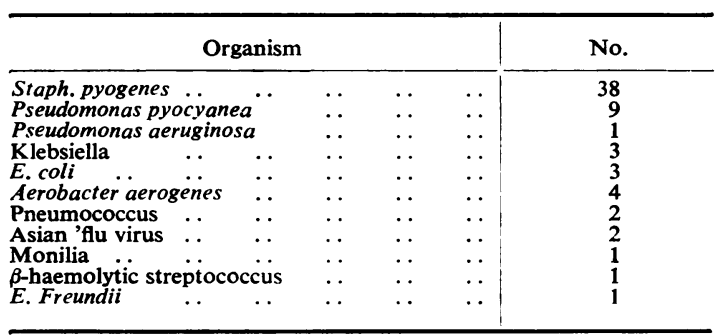

subsequently died. Moore (1958) described two cases of post-pneumonic lung abscess which occurred in children during the Asian influenza epidemic. Both children required lobectomy and made a satisfactory recovery.

Outcome Fifty-four of the 58 patients with the secondary type of lung abscess died. The diagnosis was made post mortem in the majority of the group. In 44 of the 58 cases the abscesses in the lung were multiple. Of the four children who recovered, all had a solitary lesion seen by radiography.

\section{DISCUSSION}

The classification of lung abscess into primary and secondary is an arbitrary attempt to eliminate the confusion in the literature with regard to aetiology. Cases in the group designated by definition as secondary lung abscess are those in whom there is a pre-existing illness which allows secondary septicaemic pulmonary complications. In our series, the common pre-existing conditions were prematurity, overwhelming infection, and major congenital anomalies. Many of the last group had undergone corrective surgery. In most cases abscesses were found in the liver, peritoneum, and brain, as well as in the lung.

Various diseases producing general debility, such as leukaemia, congenital heart disease, dysautonomia, and nephrosis, predisposed to lung abscess as a terminal complication.

A consideration of the cases in our series has shown that secondary lung abscess was a common complication of the later stages of serious illnesses of almost any kind. Such abscesses were frequently not detected ante mortem either clinically or radiologically, and almost never received specific treatment.

The term 'primary lung abscess' has been applied to those cases that present acutely in an otherwise healthy child.

Except in two cases the lesion was solitary. This is in keeping with the findings of Schweppe et al. (1961).

The commonly quoted predisposing factors in the formation of lung abscess are tonsillectomy, oral sepsis and dental extraction, foreign body inhalation, prolonged debility, prolonged unconsciousness, and chronic alcoholism (Fifer, Husebye, Chedister, and Miller, 1961; Schweppe et al., 1961 ; Bernhard et al., 1963 ; Drake and Sones, 1951). Fourteen children in our series had no history of any recent illness. One child had had tonsillectomy only six weeks previously. Improved techniques in anaesthesia and post-operative care have done much to eliminate the complications of this operation.

Only one child gave a history of possible foreign body aspiration, and in this case no trace of the foreign body was found at bronchoscopy. In view of the number and infinite variety of foreign bodies aspirated by small children, the lack of evidence in this series of foreign body aspiration as a pre-existing factor in the formation of lung abscess is surprising. There are various explanations which may account for this deviation. Children suspected of foreign body aspiration are now being investigated and treated more promptly and thoroughly. Bronchoscopy is used in all cases of suspected foreign body aspiration, and antibiotics are prescribed to eradicate early infection. Thus few cases proceed to sepsis.

Prolonged debility in association with other diseases has been found to play a significant part in the formation of secondary lung abscess. This does not apply in the primary variety.

There are conflicting reports in the literature as to the common causative organism in the formation of lung abscess. Schweppe et al. (1961) and Pickar and Ruoff (1959) found that the streptococcus was the principal agent involved, whereas Moore and Battersby (1960), Wolcott, Coury, and Baum (1961), and Moore (1958) concluded that the staphylococcus was becoming of greater importance.

In our series the commonest aetiological organism was the pyogenic staphylococcus, which was isolated from most cases either alone or in combination with other organisms. Most of these staphylococci were resistant to penicillin.

The beta-haemolytic streptococcus was isolated from only one child. This low incidence of streptococcal infection is indicative of the overall reduction in such organisms isolated from infections of 
all kinds in children and probably reflects the widespread use of penicillin in upper respiratory tract infections.

Treatment of lung abscess over the 10 years of this study has shown a changing pattern. Two basic principles are involved, namely adequate appropriate antibiotic therapy and drainage of the abscess cavity (Waterman and Domm, 1954 ; Drake and Sones, 1961 ; Waterman, Domm, and Rogers, 1955).

As the infecting organism was a staphylococcus in most cases, a combination of antibiotics effective against this organism was used. From 1955 to 1964 this was chloramphenicol and erythromycin, with the occasional addition of penicillin. In 1964 ampicillin and methicillin became and have remained the treatment of choice.

We have had little experience in the use of cephaloridine in the treatment of lung abscess. However, in view of the frequency with which resistant pyogenic staphylococci are implicated, it may be that this drug will play a significant part in future therapy.

Drainage of the abscess cavity is important. From 1956 to 1963 the majority of patients underwent bronchoscopy. In all cases endobronchial aspiration of the abscess cavity was attempted. During 1964-65 drainage of the cavity by physiotherapy was instituted. The technique included inhalation of an aerosol solution of $10 \%$ propylene glycol, followed by percussion of the chest wall to implement coughing and drainage.

The duration of hospital stay shows no differ- ence whether bronchoscopy or physiotherapy was used, and the choice between the two remains open.

Two children required surgery. In both, the abscess was large and chronic. Progress after lobectomy was satisfactory.

\section{CONCLUSION}

Primary lung abscess in children continues to be a problem. Tonsillectomy and aspiration of foreign body in our series seem to play little part in the aetiology of lung abscess formation. Pyogenic staphylococcus is the commonest causative organism. Treatment should include adequate antistaphylococcal therapy and drainage of the abscess cavity.

\section{REFERENCES}

Bernhard, W. F., Malcolm, J. A., and Wylie, R. H. (1963). Lung abscess: A study of 148 cases due to aspiration. Dis. Chest, 43 620.

Drake, E. H., and Sones, F. M., Jr. (1951). The management of lung abscess, with special reference to the place of antibiotics in therapy. Ann. intern. Med., 35, 1218.

Fifer, W. R., Husebye, K., Chedister, C., and Miller, M. (1961). Arch. intern. Med., 107, 668.

Moore T. C. (1958). Lobectomy for postpneumonic lung abscess in infancy and childhood. Surgery, 44, 741 .

- and Battersby, J. S. (1960). Pulmonary abscess in infancy and childhood: report of 18 cases. Ann. Surg., 151, 496.

Pickar, D. N., and Ruoff, W. F. (1959). Pulmonary abscess: a study of 70 cases. J. thorac. Surg., 37, 452.

Schweppe, H. I., Knowles, J. H., and Kane, L. (1961). Lung abscess: an analysis of the Massachusetts General Hospital cases from 1943 through 1956. New Engl. J. Med., 265, 1039.

Waterman, D. H. and Domm, S. E. (1954). Changing trends in the treatment of lung abscess. Dis. Chest, $25,40$. and Rogers, W. K. (1955). Lung abscess-a medicosurgical problem. Amer. J. Surg., 89, 995.

Wolcott, M. W., Coury, O. H., and Baum, G. L. (1961). Changing concepts in the therapy of lung abscess: a twenty year survey. Dis. Chest, 40, 1. 